University of Pennsylvania Carey Law School

Penn Law: Legal Scholarship Repository

Faculty Scholarship at Penn Law

$3-2021$

\title{
How Criminal Code Drafting Form Can Restrain Prosecutorial and Legislative Excesses: Consolidated Offense Drafting
}

\author{
Paul H. Robinson \\ University of Pennsylvania Carey Law School \\ Matthew Kussmaul \\ Ballard Spahr LLP \\ Muhammad Sarahne \\ University of Pennsylvania Law School
}

Follow this and additional works at: https://scholarship.law.upenn.edu/faculty_scholarship

Part of the Criminal Law Commons, Criminology and Criminal Justice Commons, Law and Politics Commons, Law and Society Commons, Law Enforcement and Corrections Commons, Legislation Commons, Public Law and Legal Theory Commons, and the State and Local Government Law Commons

\section{Repository Citation}

Robinson, Paul H.; Kussmaul, Matthew; and Sarahne, Muhammad, "How Criminal Code Drafting Form Can Restrain Prosecutorial and Legislative Excesses: Consolidated Offense Drafting" (2021). Faculty Scholarship at Penn Law. 2115.

https://scholarship.law.upenn.edu/faculty_scholarship/2115

This Article is brought to you for free and open access by Penn Law: Legal Scholarship Repository. It has been accepted for inclusion in Faculty Scholarship at Penn Law by an authorized administrator of Penn Law: Legal Scholarship Repository. For more information, please contact PennlawIR@law.upenn.edu. 


\title{
ARTICLE
}

\section{HOW CRIMINAL CODE DRAFTING FORM CAN RESTRAIN PROSECUTORIAL AND LEGISLATIVE EXCESSES: CONSOLIDATED OFFENSE DRAFTING}

\author{
Paul H. Robinson, ${ }^{*}$ Matthew G. Kussmaul, $\dagger$ \\ $\&$ Muhammad Sarahne +
}

\begin{abstract}
Solving criminal justice problems typically requires the enactment of new rules or the modification of existing ones. But there are some serious problems that can best be solved simply by altering the way in which the existing rules are drafted rather than by altering their content. This is the case with two of the most serious problems in criminal justice today: the problem of overlapping criminal offenses that create excessive prosecutorial charging discretion and the problem of legislative inconsistency and irrationality in grading offenses.

After examining these two problems and demonstrating their serious effects in perverting criminal justice, the essay proposes a particular method of drafting criminal offenses - consolidated offense drafting —and then shows how this drafting approach is the best and perhaps the only effective means of solving the problems. Potential political resistance to the proposal is discussed.
\end{abstract}

\section{TABLE of Contents}

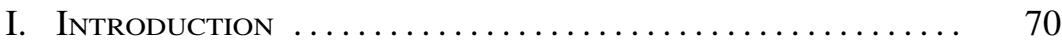

II. The Problem of Excessive Prosecutorial Power Created by Overlapping Offenses ................ 70

A. Examples of Overlapping Offenses .............. 71

B. Why Are Overlapping Offenses So Problematic? ...... 74

III. The Problem of Legislative Inconsistency and IrRAtionality in OfFEnSE Grading ............... 78

A. Non-Modern Code Jurisdictions ............... 79

B. Modern Code Jurisdictions ...................... 80

* Colin S. Diver Professor of Law, University of Pennsylvania, and former director of criminal law recodification projects in Illinois, Kentucky, Delaware, and several countries overseas. The authors give special thanks to Sarah Robinson for invaluable research assistance and to Michael Serota and Nyssa Taylor for useful comments. (c) Paul H. Robinson. LLP.

$\dagger$ Litigation Associate, White Collar Defense/Internal Investigations Group, Ballard Spahr

$\ddagger$ S.J.D., 2020, University of Pennsylvania Law School, and Assistant to the Deputy Attorney General, Ministry of Justice, Israel. 
C. What Causes Offense Grading Irrationalities? ........ 82

IV. The Solution: "Consolidated Offense Drafting” ..... 84

V. Restraining Prosecutorial Multiple-

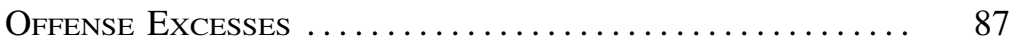

VI. Avoiding Irrational Legislative Offense Grading ... 90

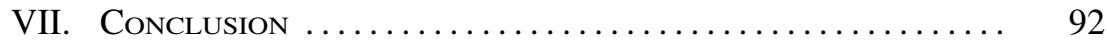

Appendix A Consolidated Delaware Statutes .............. 95

Appendix B Consolidated Illinois Statutes ................ 99

\section{INTRODUCTION}

Solving criminal justice problems typically requires the enactment of new rules or the modification of existing ones. But there are some serious problems that can best be solved simply by altering the way in which the rules are drafted rather than by altering their content. This is the case with two of the most serious problems in criminal justice today: the problem of overlapping criminal offenses that create excessive prosecutorial charging discretion and the problem of legislative inconsistency and irrationality in grading offenses and variations of an offense.

Part II of this Article describes the problem of overlapping offenses and the excessive power that such offenses give to prosecutors. Included here are examples from federal and state statutes, as well as specific illustrations of the resulting problems. The next Part examines the problem of inconsistent and irrational offense grading, i.e., the classification of offenses into groups that typically fix the maximum available punishment. ${ }^{1}$ Examples are provided from both modern and old-style codes, and these examples are used to illustrate the problems that such drafting creates.

After examining the two kinds of problems, Part IV proposes a particular method of drafting - consolidated offense drafting — which means bringing all offenses related to a certain wrongdoing under one single offense. Part IV further illustrates how the proposed method would work in practice. The next two Parts demonstrate how this drafting approach can help solve the problems of overlapping offenses and legislative irrationalities in offense grading.

\section{The Problem of Excessive Prosecutorial Power Created by Overlapping OfFenses}

It is not uncommon in American criminal codes for a single criminal act to violate several different criminal statutes. Sometimes this makes good

\footnotetext{
${ }^{1}$ Most criminal codes, and essentially all modern codes, have a system of offense grading, such as first-degree felony, second-degree felony, etc., with a maximum authorized sentence attached to each offense grade. See, e.g., 18 Pa. Cons. Stat. $\$ 106$ (2020); Tex. Penal Code AnN. §§ 12.21-35 (West 2019); Del. Code AnN. tit. 11, § 4205 (2020).
} 
sense: a person who commits murder by burning down a house with the victim inside is properly charged and convicted of both murder and arson. The killing and the property destruction by fire are separate results and distinct harms, each of which deserves punishment.

Unfortunately, it is often the case that American criminal codes contain multiple offenses for a single criminal act where the offenses are simply overlapping prohibitions of the same instance of wrongdoing. For example, several offenses may target the same base harm and differ only in the substitution of one or more aggravating factors. An offender who steals a gun from a state museum has committed a single wrong. In grading the seriousness of the theft, we may want to take special account of the fact that the property stolen belongs to the state, the victim of the offense was a museum (a charitable institution), and the item stolen was a firearm. But it hardly makes sense for the law to treat the person as having committed three (or more) separate offenses by allowing the thief to be charged under multiple overlapping statutes: the general theft statute, which probably has different grades based upon the value of the property; a special theft-of-state property offense; a special theft-from-museum offense; and a special theft-of-firearm offense.

In this Part, we will give examples of different kinds of overlapping offenses and explain why they are so problematic.

\section{A. Examples of Overlapping Offenses}

Overlapping offenses are common in American criminal codes. For example, in federal law, the proliferation of interrelated fraud offenses makes it a regular practice for a defendant accused of participation in a single scheme to be charged with a handful of overlapping offenses. In August 2019, the Department of Justice charged Michael Hild with wire fraud, ${ }^{2}$ bank fraud, ${ }^{3}$ securities fraud, ${ }^{4}$ and conspiracy ${ }^{5}$ to commit all three offenses for orchestrating a scheme to deceive lenders (including a bank) to lend to Live Well Financial, of which Mr. Hild was CEO, by inflating the value of the company's bond portfolio. ${ }^{6}$ The bank's involvement aggravated Mr. Hild's situa-

${ }^{2} 18$ U.S.C. $\S 1343$ (2018) (carrying a maximum sentence of thirty years where, as here, the fraud "affects a financial institution").

${ }^{3} I d$. $\$ 1344$ (carrying a maximum sentence of thirty years).

${ }^{4}$ See 15 U.S.C. $\$ 78 \mathrm{j}$ (2018) (defining violation by reference to 17 C.F.R. $§ 240.10 b-5$ ); $i d$. $\$ 78 \mathrm{ff}(\mathrm{a})$ (criminal penalties, including maximum sentence of twenty years).

${ }^{5} 18$ U.S.C. $\S 1349$ (2018).

${ }^{6}$ See Press Release, Dep't of Justice, Former CEO of Live Well Financial Charged in \$140 Million Bond Fraud Scheme (Aug. 29, 2019), https://www.justice.gov/usao-sdny/pr/formerceo-live-well-financial-charged-140-million-bond-fraud-scheme [https://perma.cc/DE3F5VH4]; Sealed Indictment, United States v. Michael Hild, U.S. AttorneY's OfFICE, S.D.N.Y., https://www.justice.gov/usao-sdny/press-release/file/1198561/download [https://perma.cc/ 73W6-9CY8]. 
tion both by allowing a bank fraud charge and by increasing the maximum sentence of his wire fraud charge. ${ }^{7}$

Indeed, the Department of Justice had even more fraud offenses available that it could have charged. It could have used the federal criminal code's general offense for "[f]rauds and swindles" (which, like wire fraud, would have carried an aggravated maximum sentence of thirty years because the fraud "affect[ed] a financial institution"). ${ }^{8}$ Or, a Title 18 "[s]ecurities and commodities fraud" offense was also available (carrying a maximum sentence of twenty-five years) that (as to registered securities) is coextensive with the Title 15 offense under which Mr. Hild was charged. ${ }^{9}$

The Model Penal Code, promulgated in 1962 by the American Law Institute, created a modern criminal code format that significantly reduced such overlapping offenses-but not for long. ${ }^{10}$ The three-quarters of the states that re-codified their criminal codes in the following several decades generally adopted this non-overlapping approach. ${ }^{11}$ Unfortunately, as these Model Code jurisdictions created new offenses or added new grading distinctions for an offense, they typically did not integrate the refinement into the existing offense structure but rather created an entirely new offense. That

${ }^{7}$ In parallel proceedings, the Securities and Exchange Commission charged Mr. Hild under various civil anti-fraud provisions for the same scheme, seeking a permanent injunction, financial penalties, and an officer and director bar against him. See Press Release, Securities and Exchange Commission, SEC Charges Private Lender and CEO with Fraudulent Mismarking Scheme (Aug. 29, 2019), https://www.sec.gov/litigation/litreleases/2019/lr24579.htm [https://perma.cc/24FB-JFN7]; Complaint, United States Securities and Exchange Commission v. Live Well Financial, Inc., No. 1:19-cv-8086 (S.D.N.Y. Aug. 29, 2019), https:// www.sec.gov/litigation/complaints/2019/comp24579.pdf [https://perma.cc/9D8V-6MW9]. As of the writing of this Article, Hild's case is still pending. See Chris Clow, Former Live Well CEO Enlists New Lawyers as Trial Approaches, Reverse Mortgage Daily (June 22, 2020), https://reversemortgagedaily.com/2020/06/22/former-live-well-ceo-enlists-new-lawyer-astrial-approaches/ [https://perma.cc/FK8G-KVR5].

${ }^{8} 18$ U.S.C. $\S 1341$ (2018).

${ }^{9}$ Id. $\S 1348$. Furthermore, if the acts underlying Mr. Hild's wire fraud charge had been his second such act within ten years, those acts would form a "pattern of racketeering activity," opening Mr. Hild up to racketeering charges. See id. § 1962(c) (defining the offense); id. $\S 1961(1)(B)$ (defining "racketeering activity" to include conduct indictable as wire fraud under 18 U.S.C. § 1343 (2018)); id. § 1961(5) (defining "pattern of racketeering activity"); id. $\S 1963$ (establishing criminal penalties, with a maximum sentence of twenty years). The same conduct may also expose a defendant to punitive enforcement actions by government agencies. For example, where securities fraud is involved, a defendant is usually also exposed to parallel enforcement for the same conduct by the Securities and Exchange Commission-which, although technically engaged in civil enforcement, wields punitive measures such as fines, permanent injunctions, and various types of bars in addition to purely remedial measures such as disgorgement of ill-gotten gains. See Gayle E. Littleton et al., Fines, Disgorgement, Injunctions, Debarment: The US Perspective, Glob. Investigations Rev. (Jan. 3, 2020), https://globalinvestigationsreview.com/benchmarking/the-practitioners-guide-to-global-investi gations-fourth-edition/1212392/fines-disgorgement-injunctions-debarment-the-us-perspective [https://perma.cc/UR9L-MENV].

${ }^{10}$ Paul H. Robinson et al., The Modern Irrationalities of American Criminal Codes: An Empirical Study of Offense Grading, 100 J. CRIM. L. \& CRIMINology 709, 711-12 (2010) [hereinafter The Modern Irrationalities].

${ }^{11}$ Id. at 711; see also Paul H. Robinson, The Rise and Fall and Resurrection of American Criminal Codes, 53 U. Louisville L. Rev. 173, 173 (2015) [hereinafter The Resurrection]. 
is, they layered the new offense or new offense grading factor on top of the existing offense structure. ${ }^{12}$ This unfortunate legislative habit recreated the problem of overlapping offenses in even the modern Model Penal Codebased jurisdictions. And, of course, in non-Model Penal Code jurisdictions, there was rarely any effort to avoid the creation of overlapping offenses.

The extent of such layered-on additions is enormous and accelerating. ${ }^{13}$ For example, it is not uncommon today for Model Penal Code jurisdictions to have codes that are four, five, or six times longer than the original. ${ }^{14}$ As the number of new criminal statutes has increased, so too has the problem of overlapping offenses.

For example, Mark Farmer, a thirty-six-year-old convicted felon from Kentucky, was arrested with a defaced sawed-off shotgun in his possession. He was charged ${ }^{15}$ with both possession of a defaced firearm (a Class A misdemeanor punishable by three months to one year in prison and fines), ${ }^{16}$ and possession of a firearm by a convicted felon (a Class $\mathrm{D}$ felony punishable by one to five years in prison and fines). ${ }^{17} \mathrm{Had}$ he been arrested with that weapon in his pocket on a school's campus, he could have been prosecuted under two additional offenses: carrying a concealed deadly weapon (a Class A misdemeanor $)^{18}$ and unlawful possession of a weapon on school property (a Class D felony). ${ }^{19}$ Nothing in Kentucky's penal code appears to prohibit finding such an offender guilty of all four of these offenses. ${ }^{20}$ There are not four separate wrongdoings here, but rather a single wrongdoing with four different prohibited characteristics. While each factor bears on the seriousness of Mr. Farmer's conduct, he committed a single criminal act.

Similarly, in Delaware, a person who recklessly inflicts bodily injury upon an elderly person who suffers from a mental or physical disability, by hitting him with a car, may be charged with vehicular assault in the third degree (a Class B misdemeanor punishable by up to six months in prison, besides fines and restitution), ${ }^{21}$ abuse of an adult who is impaired (a Class A misdemeanor punishable by up to one year in prison, in addition to other penalties), ${ }^{22}$ and a crime against a vulnerable adult (a Class $\mathrm{G}$ felony, punish-

${ }^{12}$ Paul H. Robinson \& Michael T. Cahill, The Accelerating Degradation of American Criminal Codes, 56 Hastings L.J. 633, 635-44 (2005) [hereinafter The Accelerating Degradation].

${ }^{13} I d$.

${ }^{14}$ Id. at 635-36. See also Paul H. Robinson et al., U. of Penn. Crim. L. Research Grp., Report of the Delaware Criminal Law Recodification Project 114-15, 400-02 (2017) [hereinafter Delaware Report].

${ }^{15}$ Matthew DeVault, Rosine Man Faces Defaced Weapon, Drug Related Charges, 14 News (June 8, 2019), https://www.14news.com/2019/06/08/rosine-man-faces-defacedweapon-drug-related-charges/ [https://perma.cc/3E55-ED5G].

${ }^{16}$ Ky. Rev. Stat. AnN. § 527.050(2) (West 2020).

${ }^{17}$ Id. $\$ 527.040$.

${ }^{18} I d . \S 527.020$.

${ }^{19}$ Id. $\$ 527.070$.

${ }^{20}$ Id. $\S 505.020$.

${ }^{21}$ Del. Code Ann. tit. 11, § 628 (2020).

${ }^{22}$ Del. Code AnN. tit. 31, § 3913 (2020). 
able by up to two years in prison). ${ }^{23}$ There is nothing in Delaware's criminal code that would seem to prohibit conviction for all three offenses.

In New Jersey, a person who provides an arrestee with a tool to help him escape from a detention facility may be prosecuted for providing escape implements, ${ }^{24}$ permitting/facilitating escape ${ }^{25}$ (both crimes of the third degree, punishable by three to five years in prison and fines), and obstructing administration of the law (a crime of the fourth degree if the offender obstructs the detection, investigation or prosecution of another, punishable by a maximum eighteen months in prison and fines). ${ }^{26}$

In Illinois, if a person possesses a motor vehicle valued at $\$ 50,000$, knowing it has been stolen from a police department in the state, he may be prosecuted for theft (a Class 1 felony, because the theft is of governmental property that exceeds $\$ 10,000$ but not $\$ 100,000$, punishable by four to fifteen years in prison and up to a fine of $\$ 25,000),{ }^{27}$ unlawful possession of a stolen motor vehicle (a Class 2 felony, punishable by three to seven years in prison, and up to a fine of $\$ 25,000),{ }^{28}$ and aggravated possession of a motor vehicle (a Class 1 felony). ${ }^{29}$ Illinois' criminal code permits prosecution of multiple offenses violated by the same conduct, and does not prevent convictions for all of these offenses. ${ }^{30}$ It was left to the courts to develop doctrines that might limit conviction for multiple overlapping offenses. ${ }^{31}$

As one can clearly see, overlapping offenses are diverse, and they are everywhere.

\section{B. Why Are Overlapping Offenses So Problematic?}

Such overlapping offenses are problematic for a variety of reasons. First, they undermine the rule of law by shifting essential criminalization decisions from the legislature onto the prosecutor. While it is properly for the legislature to define what conduct is criminal and the relative seriousness of each offense, multiple overlapping offenses essentially transfer that criminalization and grading authority to the discretion of the prosecutor (and sometimes to the court). The prosecutor is free to pick which of the overlapping offenses she will charge, and thus which offense grade will apply. Or, the prosecutor may decide ad hoc to charge any combination of the multiple overlapping offenses.

\footnotetext{
${ }^{23}$ Del. Code Ann. tit. 11, § 1105 (2020).

${ }^{24}$ N.J. Stat. AnN. \& 2C:29-6 (West 2020).

${ }^{25} I d . \$ 2 \mathrm{C}: 29-5$.

${ }^{26}$ Id. § $2 \mathrm{C}: 29-1$.

27720 Ill. Comp. Stat. 5/16-1(b)(5.1) (2020).

${ }^{28} 625$ Ill. Comp. Stat. 5/4-103(a)(1), (b) (2020).

${ }^{29}$ Id. 5/4-103.2(a)(6), (c).

30720 Ill. Comp. Stat. 5/3-3 (2020).

${ }^{31}$ See, e.g., People v. Harvey, 813 N.E.2d 181, 197 (Ill. 2004) (reversing the conviction of four counts of unlawful possession of stolen motor vehicle, as the possession of the four vehicles constituted one count of aggravated possession).
} 
Second, the use of overlapping offenses creates an inappropriate power for prosecutors to use threats of excessive punishment to extract plea bargains. Charging the offender with four separate offenses that substantially overlap with one another threatens enormous total liability exposure, an exposure far beyond the amount of liability and punishment that the offender deserves. It is the overlapping nature of the offenses that creates the exposure to excessive liability and punishment, yet it is this very threat of excessive punishment that gives the prosecutor the leverage to get a "better" plea. ${ }^{32}$ Courts have a very limited oversight, if any, of plea bargains,$^{33}$ and thus they lack the ability to restrain prosecutors' imbalanced power to overcharge and mitigate offenders' exposure to excessive liability and punishment created by overlapping offenses. This problem is exacerbated by the fact that the overwhelming majority of cases end in guilty pleas, ${ }^{34}$ and it underscores the pressing need for a legislative reform. Moreover, the vast majority of American jurisdictions employ an open-ended discretionary regime with regard to the law of cumulative punishments, meaning it is up to the judge to decide whether multiple punishments inflicted upon a defendant would run consecutively or concurrently. Thus, prosecutors retain their excessive leverage under these regimes, since plea negotiations take place before the sentencing, and the defendant may not be certain whether the judge would favor concurrent or consecutive sentences. ${ }^{35}$

One might argue that this excessive power simply makes it easier for a prosecutor to get a plea to an offense that best matches her perception of the offender's deserved punishment. But this sort of outsized power disconnects the plea process from the actual facts of the case and ties it more to the peculiarity of the offense overlaps that exist in that area of law. Ideally, under a criminal code without overlapping offenses, plea bargaining and its result would depend, and rightfully so, on counsels' perceptions of the strength of their cases and the risks of going to trial. However, the existence of overlapping offenses in the code changes the process of plea bargaining significantly, as its result would depend also on the prosecutor's ability to threaten conviction for multiple overlapping offenses that would seriously over-punish the offender. ${ }^{36}$ Further, it substitutes the prosecutor's judgment about the seriousness of the offense for the judgment of the legislature (as well as for the judgment of the judge and jury).

${ }^{32}$ Andrew M. Crespo, The Hidden Law of Plea Bargaining, 118 Colum. L. Rev. 1303, 1313-14 (2018).

${ }^{33}$ See generally Jenia I. Turner, Plea Bargaining, in 3 Reforming Criminal Justice: Pretrial and Trial Processes 73 (Erik Luna ed., 2017).

${ }^{34} \mathrm{Id}$. at 73 ("More than $95 \%$ of convictions in the federal and state systems are the product of negotiated guilty pleas." (citing Bureau of Justice Statistics, U.S. Dep't of Justice, Federal Justice Statistics 2012-Statistical Tables 17 tbl.4.2 (2015))).

${ }^{35}$ Crespo, supra note 32, at 1332-38.

${ }^{36}$ See Kyle Graham, Crimes, Widgets, and Plea Bargaining: An Analysis of Charge Content, Pleas, and Trials, 100 CALIF. L. Rev. 1573, 1577, 1582 (2012); see also Crespo, supra note 32 , at 1313 . 
Third, overlapping offenses create the danger of punishment beyond what is deserved if the prosecutor chooses to prosecute several or all of the available offenses. In the examples above, one could hardly suggest that punishment proportionate to the seriousness of the offense can be reached by treating each of the overlapping offenses as an independent wrong, with the offender punished separately for each of them. What we are left with when a prosecutor takes the multiple-overlapping-offense path is the very messy task of trying to have a sentencing judge disentangle the extent of the overlap.

A few jurisdictions adopted a statutory provision like Model Penal Code section 1.07, which prevents conviction for certain multiple related offenses ${ }^{37}$ but even in these minority jurisdictions, the statutory provision will be of limited help to a sentencing judge. Most of its provisions prevent conviction for multiple related offenses different than those creating the problems described above. For example, it prevents conviction for both the substantive offense and an inchoate offense toward that substantive offense,,$^{38}$ prevents conviction for offenses that require inconsistent findings of fact, ${ }^{39}$ and prevents conviction for both an offense and a lesser included offense. ${ }^{40}$ But these multiple-offense limitations do not avoid the problem of overlapping offenses. The troublesome overlap that we discussed here are instances where, for example, each of two offenses focus on a different aggravating factor. Neither is a lesser included offense of the other: they are distinct, but overlapping, offenses.

Another reason judicial discretion cannot solve the overlapping offense problem is that judges commonly have limited and inflexible tools at their disposal. They can convict for only one, instead of both, of the overlapping offenses; but that has the effect of completely ignoring the part of the dismissed offense that is not part of the overlap. For example, where two offenses each focus on a different aggravating factor, one of the aggravating factors will now be entirely ignored. Alternatively, the judge could allow conviction for both offenses but then have the sentences run concurrently. But again, that completely ignores the non-overlapping part of the offenses. Each aggravating factor ought to provide some additional weight to the sen-

${ }^{37}$ See Model Penal Code $§ 1.07$ cmt. 1-6 (Am. L. Inst. 2007). Similarly, several jurisdictions attempt to address the problem of overlapping offenses by statutorily adopting, in their penal codes, the double-jeopardy rule, according to which a defendant may not be convicted of greater and lesser included offenses for the same underlying conduct. See, e.g., Del. Code Ann. tit. 11, § 206 (2020); N.J. Stat. Ann. § 2C:1-8 (West 2020); Ky. Rev. Stat. Ann. $\S 505.020$ (West 2020).

${ }^{38}$ Model Penal Code $\S 1.07(1)(b)$ (Am. L. Inst. 1985). Provisions like this prohibit, for example, conviction of both murder and attempted murder of the same victim.

${ }^{39}$ Id. $\S 1.07(1)(c)$. Provisions like this prohibit, for example, conviction of both robbery and receiving stolen property.

${ }^{40} I d . \S 1.07(1)(\mathrm{a}),(4)$. Provisions like this prohibit, for example, conviction of both murder and manslaughter for killing the same person. 
tence..$^{41}$ Or, the judge could have the sentences run consecutively; but that invites excessive punishment by treating the two offenses as if they were entirely separate, thereby exaggerating their collective wrongfulness. ${ }^{42}$ Further, doctrines running contrary to the principle of blameworthiness proportionality, such as mandatory minimum sentences, cabin judicial discretion even more, and restrict judges' ability to alleviate the disproportional results created by the problem of overlapping offenses.

The larger point here is that any judicial exercise of discretion as a means of solving the problem is just another mode by which the legislative role of determining the proper grading for an offense may be usurped. The legislative role is here being usurped by the judge rather than the prosecutor. It is the legislature that should be making the judgments as to what grading factors are more serious or less serious, or whether some factors ought to merge.

Fourth, the use of overlapping offenses and the prosecutorial discretion that likely follows creates disparity in the treatment of similar cases. Different prosecutors can have different judgments about the relative seriousness of different offenses or the deserved punishment of different offenders. One prosecutor might charge all available offenses, while another might charge the offense closest to her judgment of the seriousness of a particular act, while yet another might choose leniency and charge the least serious offense. The discretion that overlapping offenses give to the prosecutor essentially ensures that there will be disparity in the treatment of similar offenders according to an offender's good or bad luck in the prosecutor she gets.

Fifth, a practice of multiple overlapping offenses also undercuts the rule of law by making law so complex and obscure that even those who want to know the law will have difficulty learning it. In a nonoverlapping code, like the Model Penal Code, even a high school student could look at the table of contents and find the particular offense definition that applies to the conduct they have a question about, and that provision will both define the offense and specify the grade of the offense or each distinct suboffense. But in today's codes, it is a nearly impossible task to find and reconcile the many overlapping offenses scattered across different places in the criminal code and commonly even outside of the criminal code. And even the profession-

${ }^{41}$ A clever judge might try to game the system by giving concurrent sentences but increasing the sentence length of the more serious offense in order to take into account the aggravating factor that is the focus of the other offense (with a concurrent term). But, setting aside the obvious problem of disparity among judges, it would be difficult to justify a system with such a lack of transparency as an acceptable solution to the overlap problem.

${ }^{42}$ The federal sentencing guidelines provide a mechanism to somewhat reduce the extent of the consecutive-versus-concurrent problem. The federal guidelines have each offense count for something, but progressively less for each additional offense, with offenses ordered by severity. See U.S. Sentencing Guidelines Comm'n, Guidelines Manual § 5G1.2 (2018). But even if this solution to the consecutive-concurrent problem is adopted, there still remains a problem with overlapping offenses. The additional overlapping offenses will trigger some additional penalty under the federal guidelines approach, when in fact no additional penalty is appropriate because there is no separate harm or wrongdoing in the overlapping offenses. 
als cannot know the law without relying on the assistance of research and compilation services from companies like Lexis or Westlaw and, often, investing a significant amount of time. Therefore, the practice of multiple overlapping offenses infringes upon the legality principle and the fundamental fair warning requirement derived therefrom. The Supreme Court of the United States has emphasized the paramount importance of this requirement, noting that because a "man is free to steer between lawful and unlawful conduct, we insist that laws give the person of ordinary intelligence a reasonable opportunity to know what is prohibited, so that he may act accordingly." 43

Finally, this same problem of ignorance of the law applies to legislators, sometimes with even more dire results. When proposing new legislation, it would seem essential for a legislator to know what law already exists on the subject. Is the proposed offense conduct already covered? In proposing the offense grade for the new offense, what grade would match the legislative grading judgments of the existing related offenses? A legislator cannot have this critical information without knowing current law, but the current state of American criminal codes, with scattered multiple overlapping offenses, makes it unrealistic that a legislator can obtain this basic information without commissioning a major research project. ${ }^{44}$ And legislative drafting in ignorance of current law regularly produces inconsistent and irrational offense grading, as illustrated in the next Part.

\section{The Problem of Legislative Inconsistency and IrRationality in OfFEnSE Grading}

Most people would agree that, other things being equal, more serious offenses should be punished more severely than less serious offenses. ${ }^{45}$ Modern criminal codes help legislators follow this principle by creating a system of offense grades, as noted previously. ${ }^{46} \mathrm{~A}$ grading scheme allows legislators to test the accuracy of their judgments about relative seriousness by asking, for example: Are all of the offenses categorized as third-degree felonies generally of the same level of seriousness? Are they all less serious than second-degree felonies and more serious than fourth-degree felonies?

Even non-modern codes that do not use an offense grading scheme presumably want consistency and rationality in setting the maximum penalties

${ }^{43}$ Grayned v. City of Rockford, 408 U.S. 104, 108 (1972).

${ }^{44}$ See, e.g., Paul H. Robinson \& U. of Penn. Crim. L. Research. Grp., Report on Offense Grading in Pennsylvania 16 (2009), https://scholarship.law.upenn.edu/ faculty_scholarship/295 [https://perma.cc/4DCY-MYJG] [hereinafter Pennsylvania Report]; Paul H. Robinson et al., Report on Offense Grading in New Jersey 12 (2011), https:// scholarship.law.upenn.edu/faculty_scholarship/340 [https://perma.cc/BCU4-BR8E] [hereinafter New Jersey Report].

${ }^{45}$ See Jesper Ryberg, The Ethics of Proportionate Punishment 12, 59-60 (2004).

${ }^{46}$ See supra note 1. 
for offenses, which will put each offense in its appropriate ordinal rank as against all other offenses: offenses with a ten-year maximum sentence ought to be more serious than offenses with a seven-year maximum sentence and less serious than offenses with a thirteen-year maximum sentence.

Judging the relative seriousness of each offense must take account of the relative seriousness of its harm or evil as against that of other offenses. For example: How damaging was the injury? What was the value of the property stolen or destroyed? What was the extent of the risk created? How many people were affected? How important was the governmental function impaired? Offense grading also may take account of culpability factors, by assigning a higher offense grade for a higher culpability level in committing the same offense conduct. Most famously, a killing that is purposeful or knowing may be murder, which is graded higher than a reckless killing, which is manslaughter, and negligent killing, which is negligent homicide..$^{47}$ Offense grading may also take account of a wide variety of other offense characteristics that, in the legislature's view, affect the overall seriousness of the offense-for example: whether the victim is a member of a particularly vulnerable class of persons; whether the offender is of a particular status, such as a public official; whether the offender and victim have a particular relationship, such as parent and child; whether the offense was committed in a particularly heinous or egregious way; whether the offender had committed the offense previously; or whether hatred of a class characteristic of the victim motivated the offender's action.

Yet, despite the consensus that criminal codes should grade an offense according to its relative seriousness as against all other offenses, the unfortunate truth is that American criminal codes generally do a poor job in this regard. The problems are most common and most serious in those jurisdictions that have failed to adopt a modern offense grading scheme, as discussed in Section A below. Section B shows how the problems nevertheless also appear in modern, model code jurisdictions, and Section $\mathrm{C}$ explores some of the common causes of grading irrationalities in American criminal law.

\section{A. Non-Modern Code Jurisdictions}

A common problem in this regard is assigning different grades to offenses involving similar conduct, for no rational reason. For example, according to the California Penal Code, if an assault is committed against a parking control officer, the offense is punishable by a maximum term of six months in prison. ${ }^{48}$ However, if the assault is committed against a highway worker, the maximum punishment would go up to one year in prison..$^{49} \mathrm{It}$ is

\footnotetext{
47 See, e.g., Model Penal Code art. 210 (Am. L. Inst. 1985).

${ }^{48}$ Cal. Penal Code $\S 241$ (b) (West 2020).

${ }^{49}$ Id. $\S 241.5$.
} 
unclear why these two cases should have these relative maximum punishments.

Federal criminal law-the most prominent example of a non-modern American code-is a rich source of inconsistencies. While destroying religious property carries a maximum punishment of three years in prison, ${ }^{50} \mathrm{de}$ stroying a veterans' memorial statue is punishable by up to ten years in prison. ${ }^{51}$ There seems little justification for the latter to have a maximum sentence more than three times greater than the former.

Grading similar offenses differently is one sort of grading irrationality, but the reverse sort of irrationality is also common: grading meaningfully different cases the same. Under California law, for example, the omission of a parent to furnish necessary clothing for her child ${ }^{52}$ has the same maximum punishment as the complete abandonment of the child by the parent. ${ }^{53}$ Both are punishable by a maximum of one year in county jail..$^{54}$ Strangely, the maximum fine in the former case is twice that of the latter. Similarly, physically injuring a juror and corruptly trying to influence a juror have the same legislative maximum penalty of ten years under the federal criminal code, because both kinds of conduct are included in the same broadly worded offense..$^{55}$

Grading irrationalities are rampant in non-modern code jurisdictions. Examples provided here are the tip of the iceberg.

\section{B. Modern Code Jurisdictions}

Unfortunately, the same kinds of inconsistencies and irrationalities are not uncommon even in modern code jurisdictions, which typically have offense grading schemes. Inconsistent grades are often assigned to offenses of similar seriousness. Pennsylvania, for example, recognizes an offense for the unauthorized administration of an intoxicant with the intent to rape. ${ }^{56}$ This is, in effect, a specific instance of the offense of attempted rape. ${ }^{57}$ Yet, the former is punishable by up to seven years in prison, while the latter carries a maximum sentence of twenty years-nearly three times the penalty. ${ }^{58}$ How much punishment the offender receives, then, will greatly depend upon which offense the prosecutor chooses to charge. In Delaware, the offense of sexual extortion is a Class $E$ felony (with a maximum of five years in prison), ${ }^{59}$ but is defined so broadly that it encompasses both sexual contact

\footnotetext{
${ }^{50} 18$ U.S.C. $\$ 247$ (2018).

${ }^{51}$ Id. § 1369.

${ }^{52}$ Cal. Penal Code $\S 270$ (West 2020).

${ }^{53}$ Id. $\$ 271$.

${ }^{54} I d . \$ \$ 270-71$.

5518 U.S.C. $\S 1503$ (2018).

5618 Pa. Cons. Stat. § 2714 (2020).

${ }^{57}$ See id. § 3121(a)(4).

${ }^{58}$ See id. $\$ 2714$.

${ }^{59}$ Del. Code Ann. tit. $11 \S 774$ (2020).
} 
and sexual intercourse-the conduct forming the offenses of unlawful sexual contact in the third degree on the one hand, and various degrees of rape on the other. ${ }^{60}$ Furthermore, both unlawful sexual contact and rape require the conduct to be "without the victim's consent," ${ }^{61}$ which, in turn, is defined to include the very kinds of threats that comprise the "extortion" in the sexual extortion offense. ${ }^{62}$ But, unlawful sexual contact is graded as a Class A misdemeanor and rape is graded anywhere from a Class $\mathrm{C}$ felony (maximum fifteen years in prison) to a Class A felony (life imprisonment), depending upon the precise circumstances. In other words, a sexual extortion charge is always either disproportionately too serious, or not serious enough, when compared with the coextensive alternative offenses. Similarly, escaping from prison in Illinois is graded less seriously than a prisoner's mere possession of a tool that may be used to escape from prison-thereby grading a preparatory step that may not rise to the level of attempt more harshly than the completed offense. ${ }^{63}$

As noted above, grading irrationalities commonly arise when offenses with a single grade are defined so broadly that acts of materially divergent seriousness are improperly punished as though they were the same. This kind of irrationality occurs even in modern codes. The law of theft in Kentucky, for example, sets a single "cut-off" level of $\$ 300$ to distinguish between the two grades of the offense, no matter what property is involved ${ }^{64}$ meaning that theft of $\$ 400$ is graded the same as theft of $\$ 4,000,000$.

Similarly, the offense of committing a second sex offense in Pennsylvania is defined so broadly as to include both a second conviction for raping another by force and a second conviction for displaying obscene materials in public: both courses of conduct carry a minimum sentence of twenty-five years in prison. ${ }^{65}$ In Delaware, the general offense for property damage, "criminal mischief," has only one felony grade: a Class G felony for $\$ 5,000$ or more in resulting damage. ${ }^{66}$ As a result, intentionally destroying the Statue of Liberty (were it located in Delaware) would be subject to the same punishment as the distinct, but less serious, Class $\mathrm{G}$ felonies, such

${ }^{60}$ Compare id. (“A person is guilty of sexual extortion when the person intentionally compels or induces another person to engage in any sexual act involving contact, penetration or intercourse.") (emphasis added), with id. $\S 767$ ("A person is guilty of unlawful sexual contact ... when the person has sexual contact with another person."), and id. §§ 770-73 ("A person is guilty of rape ... when the person: . . . intentionally engages in sexual intercourse with another person.").

${ }^{61}$ See id. $\$ \S 767,770(a)(3)(a), 771(a)(2)(a), 772(a)(1)-(2)(a), 773(a)(1)-(2)$.

${ }^{62}$ Compare id. § 761(k) ("“Without consent' means: (1) The defendant compelled the victim to submit by any act of coercion as defined in $\$ \S 791$ and 792 of this title.") and $\S 791(1)-(8)$ (defining coercion as, e.g., causing physical injury, damage to property, or engaging in other conduct constituting a crime) with id. § 774(1)-(7) (defining sexual extortion by listing the same and other similar actions).

${ }_{63} 720$ Ill. Comp. Stat. 5/31-6(a) (2020) (escape; Class 2 felony); 5/31A-1.1(d)(6) (possession; Class 1 felony).

${ }^{64}$ See Ky. Rev. Stat. Ann. $\$ 514.130$ (West 2020).

6542 Pa. Cons. Stat. $\$ 9718.2(2020)$.

${ }^{66}$ See Del. Code Ann. tit. 11, § 811(b)(1) (2020). 
as theft of $\$ 1,500,{ }^{67}$ issuing a $\$ 1,500$ bad check, ${ }^{68}$ or causing $\$ 1,501$ in property damage by an act of graffiti. ${ }^{69}$

Additionally, many modern codes apply grading factors inconsistently among different offenses, with bizarre results. In Delaware, the age of the offender is taken into account for rape, but not sexual assault. ${ }^{70}$ Under this scheme, a person who sexually assaults a twelve-year-old child is treated the same regardless of whether the offender is another twelve-year-old, or an adult. ${ }^{71}$ In Pennsylvania, the general offense of theft makes grading distinctions according to the value of the property stolen: under $\$ 50$ (third-degree misdemeanor), $\$ 50$ to $\$ 199.99$ (second-degree misdemeanor), $\$ 200$ to $\$ 2,000$ (first-degree misdemeanor), and $\$ 2,000$ or more (third-degree felony). ${ }^{72}$ In contrast, the similar offense of library or museum theft also makes grading distinctions according to the value of the property stolen, but uses different monetary cutoffs and makes fewer distinctions: less than $\$ 150$ (summary offense) and $\$ 150$ or more (third-degree misdemeanor). ${ }^{73}$ As a result, stealing property valued at $\$ 40$ is punishable with a maximum of one year if stolen from an individual, but is punishable by a maximum of ninety days if stolen from a library, and stealing a rare book valued at $\$ 3,000$ is punishable by up to seven years if stolen from an individual, but only one year if stolen from a library.

\section{What Causes Offense Grading Irrationalities?}

One may wonder why such irrationalities and inconsistencies are so common in American criminal codes, especially modern codes built upon an offense-grading scheme. The primary cause lies in the dynamics of American crime politics.

When a state's criminal laws are being codified or re-codified in a single project, it is natural at some point in the process to sort all of the offenses into their appropriate grading categories. (Of course, the minority of states without modern criminal codes have probably never undertaken this comparative classification project, so it is no surprise to find great irrationality and

${ }^{67}$ See id. $\$ 900$.

${ }^{68}$ See id. $\$ 841(\mathrm{c})(1)$.

${ }^{69}$ See id. $\S 812(\mathrm{a})(2)$.

${ }^{70}$ Compare id. $\S \S 770-73$ (rape), with id. §§ 767-69 (unlawful sexual contact).

${ }^{71}$ Compare id. $\$ 771(a)(1)$ (providing a higher grade of rape where the victim is less than fourteen years of age, and the offender is at least nineteen years of age), and id. $\S 773(\mathrm{a})(5)$ (providing an even higher grade of rape where victim is less than twelve years of age, and the offender is at least eighteen years of age), with id. § 769(a)(3) (providing a higher grade of unlawful sexual assault where the victim is less than thirteen years of age, regardless of the offender's age). Note also that the relevant age of the victim-less than twelve or less than thirteen years of age-varies between the two sets of offenses, see id. §§ 773(a)(5), 769(a)(3), but it is not clear that these different distinctions are meaningful, or whether the Delaware General Assembly was even aware of this apparent discrepancy.

7218 Pa. Cons. STAt. $\S \S 3902,3903$ (2020) (consolidated theft provisions).

${ }^{73}$ Id. $§ 3929.1$. 
inconsistency in those jurisdictions.) Thus, when a new criminal code is enacted, the code tends to have well-considered grading judgments among its offenses. The grading problems arise as those jurisdictions add new offenses over time, some criminalizing new conduct and some introducing a new offense that is a variation on an existing offense. (For example, jurisdictions may create a special offense of assault of a fireman that provides greater maximum punishment than the general assault offense.) Hundreds of new offenses are added with little regard for their relative seriousness to existing offenses. $^{74}$

Bad offense grading judgments for new offenses occur for several reasons. First, the new legislation is commonly a response to a case in media headlines, or some other triggering event has upset some constituents and motivated lawmakers to show that they are responsive to their constituents' concerns. For example, in 1992, while she was driving her two-year-old toddler, Pam Basu was forced out of her car by two men. She tried to rescue her daughter, yet her arm became entangled in the seat belt, and after she was dragged for almost two miles, she lost her life. This horrific incident shocked people nationwide, triggering Congress to create a new federal felony of carjacking, ${ }^{75}$ and motivating other state legislatures to enact harsher carjacking laws ${ }^{76}$ even though this conduct was already criminalized and carried a serious penalty. ${ }^{77}$ Unfortunately, this kind of "crime $d u$ jour" political dynamic tends to have the natural effect of exaggerating the seriousness of the offense because people are worked up at the moment about that particular conduct. The offense grade that seems appropriate in the heat of the moment stands out a year later as seriously out of line with other related offenses, but there is little political incentive to go back and correct the exaggeration. And, unfortunately, the exaggeration can provide a new baseline for the next crime $d u$ jour grading judgment. ${ }^{78}$

A second common source of bad grading judgments is legislative ignorance about existing offense grades of related offenses. That is, even if a legislator sought to be more deliberate and to consider the new offense from

${ }^{74}$ See, e.g., Pennsylvania Report, supra note 44, at 13 (noting that 2,331 criminal-offenserelated amendments were added to the Pennsylvania Crimes Code between 1972 and 2009); New Jersey Report, supra note 44, at 20 (noting that 863 criminal offense-related amendments were added to the New Jersey Code of Criminal Justice between 1979 and 2011); New Jersey Report, supra note 44, app. E (charting the number of amendments over time).

${ }^{75}$ Laura Rehrmann, Year After Fatal Carjacking, Family's Sorrow Lingers, L.A. Times (Sept. 26, 1993), https://www.latimes.com/archives/la-xpm-1993-09-26-mn-39138-story.html [https://perma.cc/RMU4-EEC4].

${ }_{76}$ Associated Press, Man Guilty in Carjacking in Which Woman Died, N.Y. Times (Aug. 15, 1993), https://www.nytimes.com/1993/08/15/us/man-guilty-in-carjacking-in-which-woman-died.html [https://perma.cc/5MKA-2N3T].

77 See Anti Car Theft Act of 1992, Pub. L. No. 102-519, 106 Stat. 3384 (codified at 18 U.S.C. § 2119 (2018)). By 2008, nearly half of the states enacted similar carjacking statutes. See Nat'l Conference of State Legislators, Auto Theft \& Carjacking State Statutes (2008), https://www.ncsl.org/print/cj/FSLautotheftpptchart.pdf [https://perma.cc/KZC2-PVCX].

${ }^{78}$ See The Modern Irrationalities, supra note 10, at 734-38, 73; The Resurrection, supra note 11 , at 181 . 
a larger perspective that takes account of the offense grades of related existing offenses, it may be difficult for the legislator to see the bigger picture, as noted in Part II. ${ }^{79}$ Once the original codification or recodification is muddied with new offenses being layered on top rather than integrated into it, it is a major research task to even find all of the existing related offenses, let alone to get a picture of a coherent grading plan that ties them together.

This may explain why grading irrationalities are getting worse, at an accelerating rate ${ }^{80}$ The messier the code becomes and the more grading irrationalities accumulate, the more difficult it is for even the conscientious legislator to find a coherent larger grading picture into which he or she can fit the new offense or offense variation.

To summarize, the crime $d u$ jour dynamic of American crime politics means that many legislators simply do not focus on getting the offense grade "correct" because their overriding concern is showing their constituents that they are responsive to the apparent problem at hand. If the legislators do focus on grading, their tendency will be to exaggerate it because of the heat of current public concern. This dynamic runs contrary to the longstanding proportionality principle in criminal law, founded upon both theoretical and empirical grounds, according to which the punishment of a crime ought to be proportional to its severity. ${ }^{81}$ But even if they try to grade the new offense to fit the larger grading pattern in existing law for related offenses, it may be difficult to pull that information together. And, if they are successful in collecting this information, they may well discover that grading consistency has already been so compromised that they are left with little or no rational guidance.

\section{The Solution: "Consolidated Offense Drafting"}

One might assume that the problems of overlapping offenses and inconsistent offense grading are intractable. Their solution seems to demand fundamental structural changes to the allocation of power and discretion on matters relating to criminal justice. How could we realistically eliminate prosecutorial discretion in the charging decision? How could we realistically constrain the legislative desire to be responsive to the crime $d u$ jour?

Interestingly, there is a realistic and workable means of reducing these problems without such dramatic_and perhaps unreachable-structural changes. The solution is possible because, rather than trying to limit the power of prosecutors and legislators generally, it aims at the dynamic that creates the problem and seeks to channel the prosecutorial and legislative power rather than to eliminate or reduce it. The solution we propose is to use

${ }^{79}$ See supra note 1.

${ }^{80}$ See The Accelerating Degradation, supra note 12, at 644-45.

${ }^{81}$ See Gregory S. Schneider, Sentencing Proportionality in the States, 54 Ariz. L. Rev. 241, 247-50 (2012). 
a particular method of defining offenses, what might be called consolidated offense drafting. Once a jurisdiction takes the step of codifying its criminal law in this format, the problems of excessive prosecutorial power from overlapping offenses and irrational and inconsistent offense grading by subsequent legislative amendment should be dramatically reduced.

The basic principle of consolidated offense drafting is to collect, in one offense definition, all of the offenses relating to a particular kind of wrongdoing that at present may be scattered across the criminal code (and beyond, in many cases). All offenses relating to theft-for example, all those carrying different maximum sentences or grading classifications because of aggravating factors-would be brought together into a single "theft offense" definition. That provision would not only define the basic offense but would also provide, in its grading subsection, the particular variations that would qualify for each different offense grade. Consolidating the factors relevant to assessing the degree of criminal liability under one single offense would demonstrate, to legislatures, the gross inconsistencies and irrationalities they have created by ad hoc offense drafting over the years. Therefore, one may assume that consolidation would prompt legislatures to re-grade the particular variations of the basic offense, according to their severity and seriousness, under the grading subsection.

To illustrate the consolidated offense drafting technique, consider proposed formulations for two common offenses, reckless injuring and tampering with public records, that were drafted to consolidate a host of related and often overlapping offenses.

RECKLESS INJURING

(a) Offense Defined. A person commits an offense if he or she recklessly causes physical injury to another person.

(b) Grading.

(1) If the injury caused is serious physical injury, then the offense is:

(A) a Class 5 felony if:

(i) injury is caused by the person's abuse or neglect of a child less than 14 years of age; or

(ii) the offense results in the unlawful termination of the victim's pregnancy without the victim's consent; or

(B) a Class 7 felony in all other cases.

(2) If the injury caused is physical injury, the offense is:

(A) a Class 8 felony if the victim is a child less than:

(i) 4 years of age; or

(ii) 14 years of age whose intellectual or physical capacity discernibly falls outside the normal range of performance and behavior with regard to age, development, and environment; or 
(iii) 14 years of age, and physical injury is caused by a deadly weapon or dangerous instrument; or (B) a Class B misdemeanor in all other cases.

This consolidated formulation is drawn from a proposal that two of us used in a project to recodify Delaware criminal law. ${ }^{82}$ The eleven existing Delaware statutes that this formulation consolidates are reproduced in Appendix A. The consolidated formulation is 173 words in length and completely replaces the eleven existing offenses that total 1472 words.

\section{Tampering with Public Records}

(a) Offense Defined. A person commits an offense if he or she:

(1) knowingly makes a false entry in, or false alteration of, any writing:

(A) belonging to, or received or kept by, the government for information or record; or

(B) required by law to be kept by others for information of the government; or

(2) knowingly alters, destroys, defaces, removes, or conceals any public record or device.

(b) Grading. The offense is:

(1) a Class 3 felony if the person is a public official or employee; or

(2) a Class 4 felony in all other cases.

The thirteen existing Illinois statutes that this formulation consolidates are reproduced in Appendix B. The consolidated formulation is 101 words in length, replacing the 13 existing offenses that total 1605 words.

The dramatic reduction of code language seen in these two illustrative formulations demonstrates how consolidated offense drafting can make criminal codes simpler, clearer, and more accessible. This promotes important interests that are impaired by overlapping offenses, as previously discussed: fair notice, uniformity in application, reduced inconsistency among different statutes, fewer troublesome interpretation issues for appellate courts, and a variety of other legality principle interests. ${ }^{83}$

One might note that the modern codification format introduced by the Model Penal Code in 1962 similarly attempted to provide a criminal code that minimized overlapping offenses. Yet that drafting approach led to the

${ }^{82}$ See Delaware Report, supra note 14 , at 114-15, 400-02.

${ }^{83}$ See id. at 19-43; Paul H. Robinson \& Michael T. Cahill, Final Report of the Illinois Criminal Code Rewrite and Reform Commission xx-lx (2003), https://scholar ship.law.upenn.edu/faculty_scholarship/291 [https://perma.cc/92QZ-TRWQ] [hereinafter Illinois Report]; Paul H. Robinson \& Kentucky Criminal Justice Council Staff, Final Report of the Kentucky Penal Code Revision Project xxiii-xxxix (2003), https://scholarship.law.upenn.edu/faculty_scholarship/294 [https://perma.cc/94YP-T7DW] [hereinafter Kentucky Report]. 
problems that we have today. Why would our proposed consolidated offense drafting do any better?

We think it would do better, and here's why. The Model Penal Code was drafted at a time when the custom was to have an enormous amount of judicial sentencing discretion. ${ }^{84}$ The goal of the criminal code at that time was simply to define the elements of the basic offense. Few offenses (such as homicide) had detailed systems of grading distinctions within the offense..$^{85}$

That world of broad judicial sentencing discretion is long gone. The sentencing guidelines movement has done much to constrain, or at least guide, the exercise of judicial sentencing discretion. ${ }^{86}$ More importantly for our purposes, legislatures have created a cottage industry of introducing a continuous and growing stream of offense grading distinctions. The result is more ambitious criminal codes that not only define the basic requirements for each offense but also set out a variety of grading distinctions that call for juries rather than judges to set the extent of liability and punishment.

In the old Model Penal Code era, when a legislator wanted to introduce a new grading distinction because of the crime $d u$ jour dynamic, or for any other reason, it was quite natural simply to create a new offense that set out the new grading distinction. Most offense definitions contained no grading distinctions to which any new distinction could be added.

Under the new approach of consolidated offense drafting, however, most if not all offenses will have a host of grading distinctions already built into the offense formulation. Indeed, under the new approach, each offense will have an "Offense Defined" section and a separate "Grading" section. At that point, when a legislator wants to introduce a new grading distinction, the easy and obvious approach will be to add it to the other grading distinctions already included in the offense's "Grading" subsection.

One might conclude that the consolidated offense drafting technique proposed here has significant advantages in clarity, brevity, accessibility, fair notice, uniformity of application, and other virtues. But how does this form of drafting rein in prosecutorial overcharging and legislative grading irrationality? That is the subject of the following two Parts.

\section{Restraining Prosecutorial Multiple-Offense Excesses}

Recall the hypothetical at the beginning of Part II involving the theft of a gun from a state museum, in which multiple overlapping statutes allow the thief to be charged with violating a variety of offenses: the general theft

${ }^{84}$ See, e.g., Susan R. Klein, The Return of Federal Judicial Discretion in Criminal Sentencing, 39 VAL. U. L. REv. 693, 693-94 (2005).

${ }^{85}$ See Michael T. Cahill, Offense Grading and Multiple Liability: New Challenges for a Model Penal Code Second, 1 OHIo St. J. Crim. L. 599, 602 (2003).

${ }^{86}$ See, e.g., Jennifer F. Reinganum, Sentencing Guidelines, Judicial Discretion, and Plea Bargaining, RAND J. ECON. 62, 78-79 (2000). 
statute, which probably has different grades based upon the value of the property; a special theft-of-state-property offense; a special theft-from-a-museum offense; and a special theft-of-a-firearm offense. Under the approach of consolidated offense drafting proposed here, multiple charges are not possible because there is only one theft offense. The special characteristics of state property, museum property, firearms, and the value of the property are all dealt with in the grading subsection of that single theft offense. The grading subsection would make clear what grade of theft is appropriate given this or any other particular combination of grading factors. ${ }^{87}$

Consider this consolidation dynamic at work in a few illustrative cases. Charles Dillard is a convicted felon from Michigan. ${ }^{88} \mathrm{He}$ was arrested while possessing a nine-millimeter gun inside a vehicle and, as a result, was charged with three overlapping offenses based on that single course of criminal conduct: possessing a firearm as a felon, carrying a concealed weapon, and possessing a firearm during the commission of a felony.$^{89}$ The trial court dismissed the third charge because prosecuting him for both possession of a firearm during the commission of a felony and possession of a firearm as a felon would infringe upon his constitutional protection against double jeopardy. ${ }^{90}$ The Michigan Court of Appeals, after employing statutory construction rules to track the legislative intent, ${ }^{91}$ concluded that double-jeopardy protection was not offended in the case and held that conviction for all three charges was permissible. ${ }^{92}$ Under the consolidated offense drafting approach, in contrast, Dillard could be neither charged with nor convicted of three separate offenses. Instead, he would be charged with one offense of firearm

${ }^{87}$ In addition to the distinctions in a "Grading" subsection, a consolidated offense section can also utilize a subsection of "Grade Adjustments" for aggravating factors that, rather than setting a baseline for the offense's grade, act to increase the grade of any version of the offense. This allows one consolidated offense section to take into account multiple aggravating factors at one time, arriving at one grade for a single course of conduct that most closely tracks the seriousness of that individual case. Two of us have used this approach with good results in the Delaware criminal law recodification project mentioned above. See Delaware Report, supra note 14, at 95-96 (general grade adjustments); Delaware Report, supra note 14, at 113 (grade adjustment for assault offense); Delaware Report, supra note 14, at 120 (grade adjustment for rape and sexual assault); Delaware Report, supra note 14, at 129 (extortion as a grade adjustment for theft offenses).

${ }^{88} \mathrm{He}$ was previously found guilty of assault with intent to murder. People v. Dillard, 631 N.W.2d 755, 757 n.1 (Mich. Ct. App. 2001).

89 Id. at 757.

${ }^{90} I d$.

${ }^{91}$ The predicate felony in this case for the felony-firearm charge was, in fact, Dillard being a felon in possession of a firearm. The court cited the language of the felony-firearm statute and remarked that it criminalizes any person who carries a firearm in his possession while committing or attempting to commit a felony, except for four exclusive felonies enumerated specifically in the felony-firearm statute. Thus, "because defendant's felon in possession charge unquestionably does not constitute one of the explicitly enumerated exceptions to the felony-firearm statute," the court concluded "that the Legislature clearly intended to permit a defendant charged with felon in possession to be properly charged with an additional felonyfirearm count." Id. at 758 .

${ }^{92}$ Id. at 760 . 
possession, whose grade and maximum punishment, according to the grading subsection of the offense, would depend on the relevant aggravating factors like concealing the firearm, possessing it while committing another felony, and the fact that he is a convicted felon.

Edward McGhee served as a vacant-lots coordinator at Project CLEAN. The project was a summer youth employment program, funded by the city of Cleveland. ${ }^{93}$ McGhee engaged in a scam that stole approximately $\$ 45,000$ from the project. ${ }^{94} \mathrm{He}$ was charged with a host of offenses and, following a bench trial, was convicted of, among other things, grand theft (due to the fact that more than $\$ 5,000$ was stolen) and theft in office. ${ }^{95}$ In his appeal before the Court of Appeals of Ohio, McGhee challenged his conviction of both offenses on the grounds that they are "allied offenses" of similar import, covering the same conduct. ${ }^{96}$ The court vacated the grand-theft conviction, explaining that the commission of theft in office automatically results in the commission of theft, and that, in this particular case, the two offenses stemmed from the same criminal actions by McGhee, with the same motive and as part of the same plan. ${ }^{97}$

Under the consolidated drafting approach, bringing multiple theft charges against McGhee would not have been an option. Instead, he could have been charged with a single theft offense. The amount of money stolen and the fact that the he used his office in aid of committing the offense, besides other characteristics of the case, would determine the appropriate theft grade, according to the theft offense's "Grading" subsection.

The result provided by the appellate court seems a proper one, but appellate case law is not a solution to the problem of multiple overlapping offenses-just as judicial sentencing discretion is not, as discussed previously. ${ }^{98}$ The prosecution still has the improper ability to overcharge and threaten excessive liability in order to gain a "better" plea bargain. It still allows for the possibility that some courts on some occasions will not properly sort out the overlapping-liability problem. And, perhaps most importantly, it leaves such criminalization decisions to the courts when they are instead appropriately legislative decisions.

Further, sometimes it is simply not within the reach of appellate court law to properly fix the problem. Recall, for example, the case of the theft of a firearm from a museum, where the offender is convicted of theft, theft of a firearm, and theft from a museum. The appellate court only has the ability to invalidate one or two of the convictions, but this does not generate the accurate result that a consolidated offense drafting provision could provide. Presumably, according to the value judgments of this particular jurisdiction,

\footnotetext{
${ }^{93}$ State v. McGhee, 523 N.E.2d 864, 866 (Ohio Ct. App. 1987).

${ }^{94} \mathrm{Id}$. at $867-68$.

${ }^{95} I d$. at $866-67$.

${ }^{96} I d$. at $873-74$.

${ }^{97}$ Id. at $874-75$.

${ }^{98}$ See supra text accompanying notes $37-42$ (discussing judicial sentencing discretion).
} 
both the firearm factor and the museum factor are aggravations. The "Grading" subsection of the theft offense might properly double the penalty of the theft offense by considering the aggravating factors present. The appellate case law simply cannot reach this result. ${ }^{99}$

Consider another example. After law enforcement seized his computer and found hundreds of child pornography images and videos on it, Joseph Benoit was indicted in a federal court for two separate offenses: the receipt of child pornography and the possession of child pornography. ${ }^{100} \mathrm{He}$ was found guilty by a jury. ${ }^{101}$ The Tenth Circuit reversed the district court's judgment and instructed it to vacate one of the convictions as the multiple sentences conflicted with the Double Jeopardy Clause. ${ }^{102}$ The court reasoned that possession of child pornography is a lesser-included offense of receipt of child pornography, as the latter necessarily requires the former, for there is no receiving without possession. ${ }^{103} \mathrm{Had}$ the federal code followed the consolidated offense drafting approach, prosecutors would not have been capable of indicting Benoit for two separate offenses. The receipt and the possession of child pornography would be part of a single consolidated child pornography offense.

Again, the fact that the federal appellate court avoided one aspect of the overlap problem in this case does not solve other problems of multiple overlapping offenses: the use of such offenses as leverage in plea bargaining; the possibility that some appellate courts will not fix the overlap problem; the fact that this criminalization decision is properly for the legislature, not the courts; and the fact that appellate courts are limited to invalidating one or another offense and have no ability to fashion an appropriate overall liability amount.

\section{Avoiding Irrational Legislative Offense Grading}

The use of consolidated offense drafting also helps solve the problem of irrational or inconsistent offense grading by the legislature. First, when a criminal code has adopted this drafting approach, legislators contemplating a new offense or adjustment to an existing offense grade will no longer have the difficult task of figuring out what current law provides. Instead of

\footnotetext{
${ }^{99}$ Note the similarity between these limitations of appellate caselaw and the limitations of the sentencing judge in the discretionary determination of consecutive versus concurrent sentences, discussed earlier. See supra text accompanying notes 37-42.

${ }^{100}$ United States v. Benoit, 713 F.3d 1, 7 (10th Cir. 2013).

${ }^{101} \mathrm{He}$ was sentenced to serve concurrent prison terms of 125 and 120 months and to pay restitution. Id. at 6.

${ }^{102} \mathrm{Id}$. at 18 .

${ }^{103}$ See id. at 12-18. In fact, the legislative history demonstrates that the possession offense was added in 1990 for gap-filling purposes, to enable targeting whoever possessed child pornography without having also received it. See id. at 15 (citing United States v. Ehle, 640 F.3d 689, 698 (6th Cir. 2011)). Since Congress has not expressed any intent to sanction both offenses separately, and Benoit was convicted of the receipt and possession offenses based on the same conduct, multiple punishments could not stand. See id.
} 
searching for related offenses that may be scattered across the criminal code and beyond, they will find all of the relevant criminal law collected in a single code provision with all of the existing grade levels represented in its grading subsection.

Further, this collection of all existing grading provisions in one subsection will set an obvious continuum of offense seriousness that will be difficult to ignore when assessing the appropriate grade for whatever new variation of the offense the legislature wishes to add. Legislators are no longer free to simply make up an offense grade in isolation. Under consolidated offense drafting, they are forced to make a comparative judgment in setting the grade: where on the continuum of current variations contained in the offense grading subsection does the proposed new variation fall?

Consider several real-world examples. Under federal law, giving or offering a bribe to a public official to influence an official act is punishable by up to fifteen years in prison. ${ }^{104}$ Yet, other bribery offenses in a variety of situations, scattered throughout the federal code, carry different, inconsistent punishments. A person who endeavors to obstruct a criminal investigation by means of bribery could be sentenced to a maximum of five years in prison. ${ }^{105}$ Giving or offering a bribe to influence inspectors or other employees of the office of any supervisor of a harbor is punishable by six months to one year in prison. ${ }^{106} \mathrm{~A}$ person who gives a bribe in exchange for acting or refraining from acting under Title 11, which regulates bankruptcy, may face a maximum of five years in prison. ${ }^{107}$ These irrational differences in grading bribery presumably exist because the legislators drafting, and voting for, each bit of legislation were unaware of the grades of the other bribery offenses. Consolidated offense drafting would quickly and easily highlight the bribery grading in current law, which would in turn help avoid inconsistency in grading new variations.

Consolidated offense drafting, by making clear the effect of grading factors in one offense, can also help avoid adopting a conflicting scheme of grading factors in similar or related offenses. For example, whatever grading scheme is used for the general damage-to-property offense, one would logically expect it to bear some relation to the grading scheme used in other kinds of damage-to-property offenses. In Delaware, a person who causes damage to property, whether intentionally or recklessly, is guilty of criminal mischief. The offense is classified as a Class $G$ felony if it is committed intentionally and the monetary loss exceeds $\$ 5,000$ or if it impairs one from a list of essential services. ${ }^{108}$ Damage valued at more than $\$ 1,000$, caused intentionally or recklessly, is classified as a Class A misdemeanor. ${ }^{109}$ Any

\footnotetext{
10418 U.S.C. $\S 201$ (2018).

${ }^{105}$ Id. $\S 1510$.

10633 U.S.C. $\S 447$ (2018).

10718 U.S.C. $\$ 152$ (2018).

${ }^{108}$ Del. Code AnN. tit. 11, § 811(b)(1) (2020).

${ }^{109} \mathrm{Id} . \S 811(\mathrm{~b})(2)$.
} 
other criminal mischief is an unclassified misdemeanor. ${ }^{110}$ However, the offense grading of other offenses addressing particular property damage in Delaware's code is highly inconsistent with the grading set forth by the criminal mischief offense. An act of graffiti is a Class A misdemeanor, and it becomes a Class $\mathrm{G}$ felony if the damage to the property exceeds $\$ 1,500^{111}$ significantly less than the threshold of a Class $G$ felony according to the criminal mischief offense. The offense of destruction of computer equipment, which criminalizes causing damage to equipment used in a computer system, ${ }^{112}$ inexplicably adopts a different grading scheme, contingent upon the amount of damage or the value of the property affected: the offense is a Class D felony if it exceeds $\$ 10,000$; a Class E felony if it exceeds $\$ 5,000$; a Class $\mathrm{G}$ felony if it exceeds $\$ 1,500$; and a Class A misdemeanor in any other case. ${ }^{113}$

These grading irrationalities presumably exist because, at the time of grading one property-damage offense, the sponsoring legislator was unaware of the grading scheme for the other property-damage offenses, or even unaware of the existence of the other property-damage offenses. By consolidating all property-damage offenses and by collecting all of the existing grading schemes in one place, consolidated offense drafting would help avoid such irrational inconsistencies.

\section{Conclusion}

Many if not most significant criminal justice reforms involve rule changes that may be difficult to enact because of conflicting political interests. The rule change may shift the balance between other competing interests, such as privacy versus law enforcement effectiveness, and on this ground the rule change may be opposed. However, as previous discussions have shown, using the proposed change in drafting technique-consolidated offense drafting - can have a dramatic effect in improving the criminal justice process even though it requires no change in the content of the rules.

Because the content of the rules is not being changed, only their statutory form, one might conclude that this kind of solution to the problems highlighted here would be without the political tensions triggered by rulechanging reforms. Unfortunately, the world is not so simple or straightforward. One of us has been involved in quite a few state criminal law recodification projects, and, in every one of those projects, prosecutors resisted the recodification plans, all of which involved some form of offense consolidation with little change in rule content. ${ }^{114}$ Why would prosecutors resist a

${ }^{110} I d . \S 811(\mathrm{~b})(3)$.

${ }^{111} I d . \S 812$.

${ }^{112} I d . \S 936$.

${ }^{113}$ Id. § 939.

${ }^{114}$ See, e.g., Alex Vuocolo, Effort to Rewrite Delaware Criminal Code Scrapped, DeL. Bus. Times (June 8, 2018), https://www.delawarebusinesstimes.com/delaware-criminal-code- 
change in drafting format that does not significantly alter the content of the existing statutes?

The answer, as signaled by the analysis in Part II, is that prosecutors wish to preserve the current chaotic structure of multiple overlapping offenses applicable to a single course of conduct. They value the outsized discretion that overlapping offenses give them. There is a slight awkwardness in this position, however, because they can hardly stand up publicly to defend what is on its face a disorganized and often impenetrable code. It is not as if any legislature ever sought to create a chaotic system of messy, overlapping offenses. The current state of affairs is simply the unfortunate effect of decades of criminal law legislation layering one new offense or offense variation on top of existing ones. No legislature defends this mess as desirable but instead reluctantly lives with it as the unfortunate byproduct of ad hoc legislative activity. When a jurisdiction does undertake a general overhaul of its criminal law, as three-quarters of the states did after the promulgation of the Model Penal Code in 1962, it never perpetuates the kind of messy overlapping offenses system that we have today. Without exception, the jurisdictions adopt new criminal codes that have as their major hallmark a structure of non-overlapping offenses, as provided in the Model Penal Code. ${ }^{115}$

Prosecutors might justify their opposition to non-overlapping recodification on the grounds that it would make their job more difficult-for example, by giving them less leverage during plea bargaining. And, in their minds, that translates into less justice done and less control of crime. However, this view reflects an unfortunate shortsightedness. As social science research increasingly shows, the long-term crime-control effectiveness of the system depends upon enhancing its reputation for being just, so as to promote community support and assistance as well as the personal internaliza-

scrapped/ [https://perma.cc/7KTE-8RVB] ("Lawmakers have scrapped an effort to overhaul Delaware's criminal code amid criticism from the attorney general. . . Attorney General Matt Denn issued a 30-page document . . . outlining the Department of Justice's concerns."); Delaware Report, supra note 14, at 11 ("[T]he Attorney General declined the invitation for his attorneys to participate in the process and eventually would not permit them to comment on the Report. As a result of this decision by the Attorney General, no one in the Department of Justice contributed to this Preliminary Report."); Illinois Report, supra note 83, at xii n.14 (explaining that Cook County State's Attorney's Office was invited to participate in review of proposed property offense drafts, "but the Office did not designate an attorney to work with the staff in such a capacity"); Kentucky Report, supra note 83, at xx ("[T] Work Group discussed the desire of the prosecutors' representatives to limit the project to proposing amendments to the existing code. Ultimately a majority of the Work Group concluded that a general rewrite of the code was the best approach to fulfilling the statutory mandate of Penal Code reform. In August 2002, the representatives of the Commonwealth's Attorneys Association and the County Attorneys Association . . . withdrew from the Work Group itself.").

${ }^{115}$ Yet, unfortunately, the drafting approach introduced by the Model Penal Code could not prevent the enactment of enormous overlapping offenses over the decades following its adoption by many jurisdictions, for the reasons explained in Part IV of this Article. 
tion of its norms. ${ }^{116} \mathrm{~A}$ criminal justice system seen as regularly unjust will instead provoke resistance and subversion and will increasingly undermine its ability to control conduct through social influence and internalized norms.

A system of messy, overlapping offenses that shifts criminal liability decisions from a criminal code's unambiguous directives to opaque prosecutorial (and judicial) discretion will undermine the system's moral credibility with the community. While the prosecutor may see short-term ease in prosecution, the long-term cost will be reduced crime-control effectiveness. The better approach is to adopt criminal codes based upon consolidated offense drafting, according to which all offenses pertinent to a single wrongdoing would be brought under one offense. This approach would reveal to legislators the significant inconsistencies and irrationalities of the existing offense grading technique and thereby prompt them to make adjustments. Armed with the facts, legislators are less likely to support grading irrationalities. They exist mainly because legislators are unaware of them.

${ }^{116}$ Paul H. Robinson, Intuitions of Justice and the Utility of Desert 95-236 (2013). 
Appendix A

Consolidated Delaware Statutes

\section{Del . Code Ann . tit. 11, $\$ 605$ (2017). Abuse of a pregnant female in the second degree; class $C$ felony.}

(a) A person is guilty of abuse of a pregnant female in the second degree when in the course of or in furtherance of the commission or attempted commission of assault third degree or any violent felony against or upon a pregnant female, or while in immediate flight therefrom, the person recklessly and without her consent causes the unlawful termination of her pregnancy.

(b) It is no defense to a prosecution under this section that the person was unaware that the victim was pregnant.

(c) Prosecution under this section does not preclude prosecution under any other section of the Delaware Code. Abuse of a pregnant female in the second degree is a class $\mathrm{C}$ felony.

\section{Del . Code Ann . tit. 11, §611 (2017). Assault in the third degree; class A misdemeanor.}

A person is guilty of assault in the third degree when:

(1) The person . . . recklessly causes physical injury to another person; . . . .

Assault in the third degree is a class A misdemeanor.

\section{Del . Code Ann . tit. 11, § 612 (2017). Assault in the second degree; class $D$ felony.}

(a) A person is guilty of assault in the second degree when:

(1) The person recklessly . . . causes serious physical injury to another person; or

(2) The person recklessly . . . causes physical injury to another person by means of a deadly weapon or a dangerous instrument; or

(10) The person recklessly ... causes physical injury to a pregnant female. It is no defense to a prosecution under this subsection that the person was unaware that the victim was pregnant; or

(11) A person who is 18 years of age or older and who recklessly . . . causes physical injury to another person who has not yet reached the age of 6 years. In any prosecution of a parent, guardian, foster parent, legal custodian or other person similarly responsible for the general care and supervision of a child victim pursuant to this paragraph, the State shall be required to prove beyond a reasonable doubt the absence of any justification offered by $\S 468(1)$ of this title. In any prosecution of a teacher or school administrator pursuant to this paragraph, the State shall be required to prove beyond a reasonable doubt the absence of any justification offered by $\S 468(2)$ of this title; or 
(12) The person recklessly . . . causes physical injury to a lawenforcement officer, security officer, fire police officer, fire fighter, paramedic, or emergency medical technician in the lawful performance of their duties by means of an electronic control device shall be a class C felony.

(d) Assault in the second degree is a class D felony.

\section{Del . Code Ann . tit. 11, §628 (2017). Vehicular assault in the third de- gree; class $B$ misdemeanor.}

A person is guilty of vehicular assault in the third degree when, while in the course of driving or operating a motor vehicle, the person's criminally negligent driving or operation of said vehicle causes physical injury to another person.

Vehicular assault in the third degree is a class B misdemeanor.

Del . Code Ann . tit. 11, § 628A (2017). Vehicular assault in the second degree; class A misdemeanor.

A person is guilty of vehicular assault in the second degree when:

(1) While in the course of driving or operating a motor vehicle, the person's criminally negligent driving or operation of said vehicle causes serious physical injury to another person; or

(2) While in the course of driving or operating a motor vehicle and under the influence of alcohol or drugs or with a prohibited alcohol or drug content, as defined by $\S 4177$ of Title 21 , the person's negligent driving or operation of said vehicle causes physical injury to another person.

Vehicular assault in the second degree is a class A misdemeanor.

Del . Code Ann . tit. 11, § 629 (2017). Vehicular assault in the first degree; class $\mathbf{F}$ felony.

A person is guilty of vehicular assault in the first degree when while in the course of driving or operating a motor vehicle and under the influence of alcohol or drugs or with a prohibited alcohol or drug content, as defined by $\S 4177$ of Title 21 , the person's negligent driving or operation of said vehicle causes serious physical injury to another person.

Vehicular assault in the first degree is a class F felony.

\section{Del . Code Ann . tit. 11, 1103 (2017). Child abuse in the third degree; class A misdemeanor.}

(a) A person is guilty of child abuse in the third degree when:

(1) The person recklessly or intentionally causes physical injury to a child through an act of abuse and/or neglect of such child; or 
(2) The person recklessly or intentionally causes physical injury to a child when the person has engaged in a previous pattern of abuse and/ or neglect of such child.

(b) This offense shall be a class A misdemeanor.

\section{Del . Code Ann . tit. 11, § 1103A (2017). Child abuse in the second de- gree; class $\mathbf{G}$ felony.}

(a) A person is guilty of child abuse in the second degree when:

(1) The person intentionally or recklessly causes physical injury to a child who is 3 years of age or younger; or

(2) The person intentionally or recklessly causes physical injury to a child who has significant intellectual or developmental disabilities;

(3) The person intentionally or recklessly causes physical injury to a child by means of a deadly weapon or dangerous instrument.

(b) This offense shall be a class $\mathrm{G}$ felony.

\section{Del . Code Ann . tit. 11, § 1103B (2017). Child abuse in the first degree; class B felony.}

A person is guilty of child abuse in the first degree when the person recklessly or intentionally causes serious physical injury to a child:

(1) Through an act of abuse and/or neglect of such child; or

(2) When the person has engaged in a previous pattern of abuse and/or neglect of such child.

Child abuse in the first degree is a class B felony.

Del. Code Ann . tit. 11, 1448 (2017). Possession and purchase of deadly weapons by persons prohibited; penalties.

(e) . .

(2) Any person who is a prohibited person as described in this section because of a conviction for a violent felony and who, while in possession or control of a firearm in violation of this section, negligently causes serious physical injury to or the death of another person through the use of such firearm, shall be guilty of a class B felony and shall receive a minimum sentence of:

a. Four years at Level V; or

b. Six years at Level $\mathrm{V}$, if the person causes such injury or death within 10 years of the date of conviction for any violent felony or the date of termination of all periods of incarceration or confinement imposed pursuant to said conviction, whichever is the later date; or

c. Ten years at Level $\mathrm{V}$, if the person has been convicted on 2 or more separate occasions of any violent felony.

d. Nothing in this paragraph shall be deemed to be a related or included offense of any other provision of this Code. Nothing in 
this paragraph shall be deemed to preclude prosecution or sentencing under any other provision of this Code nor shall this paragraph be deemed to repeal any other provision of this Code.

\section{Del . Code Ann . tit. 11, § 4134 (2017). Operation of vehicles on ap- proach of authorized emergency vehicles.}

(b) Upon approaching a stationary authorized emergency vehicle, when the authorized emergency vehicle is giving a signal by displaying alternately flashing red, blue, blue and white, red and white, red and blue, or red, white and blue lights, or upon approaching a stationary authorized vehicle of the Department of Transportation, which is giving a signal by displaying alternately flashing amber or red and amber lights, or upon approaching a stationary tow truck, which is giving a signal by displaying alternately flashing amber, white, or amber and white lights, or upon approaching a stationary vehicle owned or operated by a public utility, which is giving a signal by displaying alternately flashing amber, white, or amber and white lights, a person who drives an approaching vehicle shall:

(1) Proceed with caution and yield the right-of-way by making a lane change into a lane not adjacent to that of such vehicle, if possible with due regard to safety and traffic conditions, if on a roadway having at least 4 lanes with not less than 2 lanes proceeding in the same direction as the approaching vehicle; or,

(2) Proceed with caution and reduce the speed of the vehicle to a safe speed while passing such stationary vehicle, if changing lanes would be impossible or unsafe.

(d) Any person violating subsection (b) of this section who hits, strikes, or in any way contacts an emergency responder, causing physical injury, with that person's vehicle shall be guilty of a class F felony. 


\section{APPENDIX B \\ Consolidated Illinois Statutes}

\section{Ill . Comp. St At. 5/32-8 (2003). Tampering with public records.}

(a) A person commits tampering with public records when he or she knowingly, without lawful authority, and with the intent to defraud any party, public officer or entity, alters, destroys, defaces, removes or conceals any public record.

(b) (Blank).

(c) A judge, circuit clerk or clerk of court, public official or employee, court reporter, or other person commits tampering with public records when he or she knowingly, without lawful authority, and with the intent to defraud any party, public officer or entity, alters, destroys, defaces, removes, or conceals any public record received or held by any judge or by a clerk of any court.

(c-5) "Public record" expressly includes, but is not limited to, court records, or documents, evidence, or exhibits filed with the clerk of the court and which have become a part of the official court record, pertaining to any civil or criminal proceeding in any court.

(d) Sentence. A violation of subsection (a) is a Class 4 felony. A violation of subsection (c) is a Class 3 felony. . . .

\section{Ill . Comp. Stat. 5/33E-15 (2003). False entries.}

(a) An officer, agent, or employee of, or anyone who is affiliated in any capacity with any unit of local government or school district commits false entries when he or she makes a false entry in any book, report, or statement of any unit of local government or school district with the intent to defraud the unit of local government or school district.

(b) Sentence. False entries is a Class 3 felony.

\section{Ill . Comp. Sta t. 5/29-20 (2003). Vote by Mail ballots-violations.}

A person is guilty of a Class 3 felony who knowingly:

(4) Marks or tampers with a vote by mail ballot of another person or takes a vote by mail ballot of another person in violation of Section $19-6$. . . so that an opportunity for fraudulent marking or tampering is created.

\section{Ill. Comp. St a t. 5/29-6 (2003). Mutilation of election materials.}

Any person who knowingly destroys, mutilates, defaces, falsifies, forges, conceals or removes any record, register of voters, affidavit, return or statement of votes, certificate, tally sheet, ballot, or any other document or computer program which (a) is used or to be preserved for use in connection with registration, or (b) is used or to be preserved for use in connection with any election pursuant to this Code, except as permitted by provisions of this 
Code, shall be guilty of a Class 4 felony and shall also be ineligible for public employment for a period of 5 years immediately following the completion of his or her sentence.

\section{Ill . Сомp. Sta t. 5/1301 (2003). Willful and Fraudulent Acts.}

Any person who is subject to the provisions of this Act and who willfully fails to file a return, or who files a fraudulent return, or who willfully attempts in any other manner to evade or defeat any tax imposed by this Act or the payment thereof, or any accountant or other agent who knowingly enters false information on the return of any taxpayer under this Act, shall, in addition to other penalties, be guilty of a Class 4 felony for the first offense and a Class 3 felony for each subsequent offense. Any person who is subject to this Act and who willfully violates any rule or regulation of the Department for the administration and enforcement of this Act or who fails to keep books and records as required in this Act is, in addition to other penalties, guilty of a Class A misdemeanor. Any person whose commercial domicile or whose residence is in this State and who is charged with a violation under this Section shall be tried in the county where his commercial domicile or his residence is located unless he asserts a right to be tried in another venue. A prosecution for any act in violation of this Section may be commenced at any time within 5 years of the commission of that act.

\section{Ill. Comp. Stat. 130/14 (2003). Penalty.}

Any person required by this Act to keep records of any kind whatsoever, who shall fail to keep the records so required or who shall falsify such records, shall be guilty of a Class 4 felony. If a person fails to produce the records for inspection by the Department upon request, a prima facie presumption shall arise that the person has failed to keep the records so required. A person who is unable to rebut this presumption is in violation of this Act and is subject to the penalties provided in this Section.

\section{Ill. Comp. St at. 505/15 (2003). Offenses; penalties.}

3.5. Any person who knowingly enters false information on any supporting documentation required to be kept by Section 6 or 6 a of this Act ... is guilty of a Class 3 felony.

\section{Ill. Cомр. Stат. $657 / 90$ (2003). Enforcement.}

(h) A person who engages in conduct requiring a license under this Act and fails to obtain a license from the Director or knowingly makes a false statement, misrepresentation, or false certification in an application, financial statement, account record, report, or other document filed or required to be maintained or filed under this Act or who knowingly makes a false entry or omits a material entry in a document is guilty of a Class 3 felony. 
240 Ill. Comp. Stat. 40/15-45 (2003). Criminal offenses.

(c) A person who, knowingly and without lawful authority:

(1) withholds records from the Department;

(2) keeps, creates, or files with the Department false, misleading, or inaccurate records;

(3) alters records without permission of the Department; or

(4) presents to the Department any materially false or misleading records;

is guilty of a Class 2 felony.

410 Ill. Comp. St a t. 535/27 (2003). Violations; punishment. (1)

(b) Any person who without lawful authority and with the intent to deceive, makes, alters, amends, or mutilates any report, record, or certificate required to be filed under this Act or a certified copy of such report, record, or certificate; ... .

(f) . . is guilty of a Class 4 felony.

\section{Ill. Comp. Stat. 5/44 (2003). Criminal acts; penalties.}

(h) Violations; False Statements.

(2) Any person who knowingly makes a false material statement or representation in any label, manifest, record, report, permit or license, or other document filed, maintained, or used for the purpose of compliance with this Act in connection with the generation, disposal, treatment, storage, or transportation of hazardous waste commits a Class 4 felony. A second or any subsequent offense after conviction hereunder is a Class 3 felony.

(3) Any person who knowingly destroys, alters, or conceals any record required to be made by this Act in connection with the disposal, treatment, storage, or transportation of hazardous waste commits a Class 4 felony. A second or any subsequent offense after a conviction hereunder is a Class 3 felony.

(4) Any person who knowingly makes a false material statement or representation in any application, bill, invoice, or other document filed, maintained, or used for the purpose of receiving money from the Underground Storage Tank Fund commits a Class 4 felony. A second or any subsequent offense after conviction hereunder is a Class 3 felony.

(4.5) Any person who knowingly makes a false material statement or representation in any label, manifest, record, report, permit or license, or other document filed, maintained, or used for the purpose of compliance with Title XVI of this Act commits a Class 4 felony. Any 
second or subsequent offense after conviction hereunder is a Class 3 felony.

(5) Any person who knowingly destroys, alters, or conceals any record required to be made or maintained by this Act or required to be made or maintained by Board or Agency rules for the purpose of receiving money from the Underground Storage Tank Fund commits a Class 4 felony. A second or any subsequent offense after a conviction hereunder is a Class 3 felony.

420 Ill. Comp. Stat. 40/39 (2003). Violations.

(b)

(2) A person who knowingly alters a credential, certificate, registration, or license issued by the Department of Nuclear Safety or its successor agency, the Illinois Emergency Management Agency, for the purpose of evading a requirement of this Act is guilty of a Class A misdemeanor for a first offense and is guilty of a Class 4 felony for a second or subsequent offense.

\section{Ill. Comp. Sta t. 5/5-402.1 (2003). Use of Secretary of State Uni- form Invoice for Essential Parts.}

(f) Except for scrap processors, any person licensed or required to be licensed under Sections 5-101, 5-102 or 5-301 . . who knowingly fails to record on a Uniform Invoice any of the information or entries required to be recorded by subsections (a), (b) and (c) of this Section, or who knowingly places false entries or other misleading information on such Uniform Invoice, or who knowingly fails to retain for 3 years a copy of a Uniform Invoice reflecting transactions required to be recorded by subsections (a), (b) and (c) of this Section, or who knowingly acquires or disposes of essential parts without receiving, issuing, or executing a Uniform Invoice reflecting that transaction as required by subsections (a), (b) and (c) of this Section, or who brings or causes to be brought into this State essential parts for which the information required to be recorded on a Uniform Invoice is not recorded as prohibited by subsection (c) of this Section, or who knowingly fails to comply with the provisions of this Section in any other manner shall be guilty of a Class 2 felony. Each violation shall constitute a separate and distinct offense and a separate count may be brought in the same indictment or information for each essential part for which a record was not kept as required by this Section or for which the person failed to comply with other provisions of this Section. 